\title{
The Role of the Former combatants' reintegration on promotion of inclusion and equity in Mt. Elgon region, Kenya
}

\author{
Lydiah Wamocha ${ }^{1}$, Joseph Okumu ${ }^{2}$, Ron Pagnuco ${ }^{3}$
}

\begin{abstract}
The social reintegration of former combatants is the most important aspect of the disarmament, demobilization and reintegration (DDR) process. Post conflict societies are marked by their past traumas long after the interest of most outsiders has ebbed. Reintegration understood in this context, speaks to societal transformation, which both takes time and is prone to setbacks long after peace has formally been declared. The purpose of the study was to investigate the role of reintegration of former combatants on promotion of inclusion and equity. The objective of the study was to explain the role of the former combatants' reintegration on promotion of inclusion and equity in Mt. Elgon region. The desistance theory was used in the study. The study used the cross sectional descriptive survey design. The population of the study comprised former combatants, Sub County Commissioners, peace committee members, religious leaders and NGOs. The respondents comprised former combatants, sub county commissioners and peace committee members, religious leaders and NGOs. The stratified and purposive random sampling technique was used to select a sample of 150 former combatants, Three Sub County commissioners and 16 peace committee members, five religious leaders and Four NGO members. Data was collected by use of questionnaires, interviews and Focus Group discussion. In order to ascertain validity, the questionnaires and interview schedules were given to experts who matched all the items with the research questions to ascertain whether the instruments would measure all that it is supposed to measure. The reliability of the instruments was determined through test retest of the instruments. Data was analyzed by use of descriptive statistics of frequencies and percentages. Data from in-depth interviews was audio taped and transcribed. The transcripts were then organized into themes and categories as they emerged from the field. The findings of the study were presented descriptively. The findings of the study showed that: in the context of social reintegration the three dimensions of family and community; sustainable employment; and civic responsibilities should be given proper attention: to achieve the goal of reintegration there should be a major shift in the contemporary DDR approach by moving from the insertion approach towards a social reintegration one; community support is essential for the successful reintegration of former combatants and the sustainable social and economic reintegration of former combatants should be the ultimate objective of disarmament and demobilization and reintegration (DDR). Consequently, the study recommends that the government should budget for and give priority to the reintegration programmes so that they are fully completed instead of leaving them at the reinsertion stage; the communities take the lead in proposing community- based solutions for the issues identified.
\end{abstract}

Key word: Combatants, Demobilization, disarmament, Equity, Inclusion, Reintegration.

\section{Background to the Study}

Over the past two decades, international efforts to support the socio-economic adjustment of former combatants to the uncertain and often uneasy realities of postwar situations, have presented donor countries, NGOs and international organizations with complex, often formidable, institutional and logical challenge. Post conflict societies are marked by their past traumas long after the interest of most outsiders has ebbed. Reintegration understood in this context, speaks to societal transformation, which both takes time and is prone to setbacks long after peace has formally been declared. This phase of neither war nor peace, one that confronts so many post conflict societies, places in perspective the importance of political reintegration but also the difficulty of tailoring such processes to the individual vulnerable and opportunities afforded by the case at hand (Berda \& Ucko, 2009). 
The UN launched its new Integrated Disarmament, Demobilization and Reintegration Standards (DDRS) in order to refine its approach to DDR. One of the reasons was to ensure that ex fighters do not take up arms which was critical for stabilization of post- conflict situations. In contrast to the ad hoc disarmament and reintegration of earlier years the new standards seek to foster a comprehensive approach. They provide detailed policies, guidelines and procedures for carrying out DDR (Africa Renewal, United Nations, 2007).

\section{Reintegration of Former Combatants}

The reintegration of former combatants is often understood as the support given to offenders during their reentry into society. It includes imposing community - based sanctions rather than imprisonment in an attempt to facilitate the social integration of the offenders within the community integral part of what is commonly known as Disarmament, Demobilization and Reintegration (DDR), rather than subjecting them to the marginalization and harmful effects of imprisonment (United Nations, 2006). The postrelease, community-based component of these interventions has been variously referred to as "aftercare", "transitional care", "reentry" or "reentry support", reintegration or resettlement.

After combatants have been demobilized, their effective and sustainable reintegration into civilian life is necessary to prevent a new escalation of the conflict. In the short term, former combatants who do not find peaceful ways of making a living are likely to return to conflict. In the longer term, disaffected veterans can play an important role in destabilizing the social order and polarizing the political debate, becoming easy targets of populist, reactionary and extremist movements (Fusato, 2003).

According to Fusato (2003) the first step in reintegration of ex-combatants is their inclusion in society. He states that ex-combatants are a special group who present additional challenges since: they constitute a potential security threat; they may be viewed with fear, suspicion, and resentment by the rest of the population; they are often uprooted from their communities of origin and their social networks; they may not know or may no longer accept basic social rules.

Reintegration projects aim to assist the former combatants and their dependants in three areas: social (building new relationships and trust) political (become part of the political making process), and economic (engage in sustainable employment and livelihood) (Buxton, 2008, Torjesen, 2013). Compared to the faces of disarmament and demobilization, reintegration is seen as a long term process and has often an open time frame (Munive \& Stepputat, 2015).

Former combatants are a critical subgroup in the post conflict environment: First, former combatants who used to fight against each other encounter; second, former combatants who might have committed atrocities in their communities or victims' families; third, after years in a military environment, possibly without any contact to civilians, ex-combatants have to assimilate into civil society. These circumstances may lead to tensions and a threat for resurgent violence, especially considering the large number of former combatants. Therefore the successful reintegration is critical for peaceful co-habitation (Lotscher, 2016).

\section{Statement of the Problem}

Several actions have been taken in the past to end recruitment and use of combatants in Kenya. As a result combatants are released from the ranks of armed forces and groups and recruitment levels have progressively reduced. However, for thousands of former combatants who remain or risk re-recruitment, the situation remains substantially unchanged. The ongoing conflict in Kenya undermines the reintegration of former combatants as many of them are re-recruited by different armed groups.

After combatants have been demobilized, their effective and sustainable reintegration into civilian life is necessary to prevent a new escalation of the conflict. In the short term, ex- combatants who do not find peaceful ways of making a living are likely to return to conflict. In the longer term, disaffected veterans can play an important role in destabilizing the social order and polarizing the political debate, becoming easy targets of populist, reactionary and extremist movements.

\section{Purpose of the Study}

The purpose of the study was to investigate the role of the former combatants' reintegration on promotion of inclusion and equity in Mt. Elgon region;

\section{Research Question}

The research question was what is the contribution of reintegration of former combatants on inclusion and equity in Mount Elgon region 


\section{Theoretical Framework}

The desistance theory outlines assistance models of ex-offenders recovery into society and addresses the question of social reintegration can be perceived and structured effectively DDR operational landscape. The proposed approach is presented through a matrix of relationships between the elements of 'emphasis on the combatant' and 'emphasis on the community' in terms of 'low' and 'high' levels, resulting in the four main models for community reentry: 'self - demobilization', 'reinsertion', 'community' - located reintegration and 'social reintegration'.

From the theoretical standpoint, the desistance theory offers researchers the opportunity to test specific variables connected with the cessation of criminal behavior. It enables historical criminological approaches to be considered in relation to modern day society, which allows for validation or refutation of classical ways of thinking. This leads to a more accurate picture of criminal behavior to be painted, and enables criminology, and its related fields of psychology, politics and social policy, to collaborate strategically in order to reduce reoffending rates.

\section{Literature Review}

\section{Inclusion}

Inclusion can be described as a multidimensional process aimed at lowering economic, social and cultural boundaries between those who are included and excluded, and making these boundaries more permeable (Therborn, 2007). Lombe (2007) notes that inclusion is the realization that everyone has something to contribute. A society for all, in which every individual, each with rights and responsibilities, has an active role to play. Integration in all the forms may simply imply the existence of a stable community in which people can find a niche (Taylor, 2007). In an inclusive society, members not only have the right to education and having a vote that actually counts in a political process by which society is managed, ordered and represented.

Denov (2010) explored girl's and boy's life histories and recruitment into armed conflict, their experiences and coping strategies, as well as the long term effects of participation in war. The study used 80 children formerly associated with Sierra Leones Revolutionary United Front. The sample comprised 40 boys and 40 girls of age 14 to 21 years. There were two sets of in depth audio taped interviews with each participant. The findings were that whether as victims or as perpetrators their involvement in armed conflict had profound consequences: living with severe physical injuries and disabilities, loss of family, disturbing memories of war and violence, as well as feelings of guilt and shame and coping with rejection by families and communities. The method used to sample these children is not shown in the study.

Vindevogel et. al. (2011) carried out a study on the experiences of child soldiers in the lord's resistance army (LRA) in Northern Uganda. The socio ecological approach was used in this study. Secondary data was collected from 10,785 former child soldiers who were below 18 years from northern Uganda. Data was analyzed by the use of descriptive statistics. It was found that participants were held in captivity spent on average 1.5 years in capacity; $88 \%$ witnessed and $76 \%$ forcibly participated in atrocities; variations in exposure to warfare were associated with age of abduction, duration of captivity, location of captivity, being military trained and being a rebels wife. This study used a big enough sample that could easily be used as a reference point.

\section{Equity}

Shanahan in her study explored the contribution of Socio- ecological lens to identify social ecological lens of young mothers and their children returned from captivity in the Lord's Resistance Army, a rebel group in Northern Uganda. Rather than focusing on the reintegration experiences of the girls themselves, this study took an inverse lens and examined the process by which members of the girls' communities of origin relate to girl mothers and their babies on return. Drawing on interviews with women, men, community leaders, Acholi elders, local authorities and traditional healers, this paper engages in a situated exploration of the meanings of social ritual in post - accord healing and reconciliation, particularly spiritual reconciliation and healing rituals related to rape and sexual violence. Gave recommendations on when to give reintegration assistance and when not to.

\section{Sample Size}

The 1200 reintegrated former combatants were targeted. A sample of 150 reintegrated former combatants was taken, Four Deputy county commissioners, Six members of Cheptais, Kopsiro and Kapsokwony and Kaptama peace committees, Five church pastors and Five NGO leaders.

\section{Research Instruments}


The data was collected using questionnaires, interviews and focus group discussions. The validity and reliability of the instruments was tested. Validity is defined as the extent to which an instrument actually measures what it is supposed to measure (Dane, 1990; Kombo and Tromp, 2006). To ascertain the validity of the research instruments, the researcher sought to ensure both construct and face validity of the research instruments. Critical analysis of both test items was done to assess the relevance and appropriateness of the items in each instrument (content validity) and the sequencing, wording and instructions therein (face validity). The instruments to be used were given to experienced experts in the area who will review them and give guidance accordingly. Their comments and suggestions were used to adjust the items. This ensured that the instruments measure accurately the salient research characteristics that they intent to measure (Mugenda and Mugenda, 2003).

Reliability is defined as the degree of consistency that an instrument or procedure demonstrates (Best $\&$ Kahn, 2004). The reliability of the instruments was determined through the test retest reliability technique (Gay, 1996). This test retest method was used to confirm the reliability of the instruments. The instruments were administered to the same respondents twice within an interval of three weeks. The responses to these items were computed using the Pearson Product Moment Correlation Coefficient analysis. A correlation coefficient ' $r$ ' of 0.72 was obtained indicating the instrument was reliable and consistent for the study.

Piloting of the instruments was done in order to have a feel of the instruments, to find out if they are clear and also test for reliability. They were administered to people who have similar characteristics but not in the sampled group.

Before proceeding to collect data an introductory letter was obtained from the Catholic University of Eastern Africa. The researcher then applied for a research permit from the National Council of Science and Technology (NACOSTI). The researcher then sought permission from the CEO of the area of study.

\section{Description of Data Analysis Procedures}

After fieldwork, before data analysis, all the questionnaires were adequately checked for completeness and organization to ensure that questions were answered adequately.

Data analysis involved both quantitative and qualitative procedures. To facilitate the analysis, the raw data was summarized in tables and coded before they are entered into the computer for analysis using Statistical Package for Social Sciences (SPSS). Descriptive statistics including frequencies and percentages was used to describe the results. The quantitative analysis was supplemented by qualitative description to provide a fuller picture of the findings particularly in those areas that are not easily amenable to quantification. In addition there were verbatim quotations. Data from in-depth interviews was audio taped and transcribed. The transcripts were organized into themes and categories as they emerged from the field.

\section{The Contribution of reintegration of former combatants on inclusion and equity in Mount Elgon}

\section{Inclusion and Equity}

Avramov (2002) set out a criterion on an important role in individuals' beliefs and perspectives (e.g. dissatisfaction and self esteem) in the determination of inclusion and exclusion. Exclusion is as a rule associated with social stigmatization, blame and isolation, which translated to low self esteem, a feeling of not belonging, and not having been given a chance to be included in the society.

The Peace Tree Network organizers tried to enhance capacities and inclusion of the Mount Elgon youth in the National Reform Processes so as to solve the long standing land issue and improve their livelihood but all the efforts seemed to fail as the violence escalated.

In an oral interview the former combatants recommended the various organizations that helped them to be included in the community activities such as acquiring land in the forest and being funded to cultivate in groups. Poultry farming activities were also funded by the organizations. Besides farming they were also funded to engage in other business activities like basketry.

The project objectives were hoped that in the long run would have contributed towards fostering the development of a democratic culture in Mt. Elgon based on respect of human rights. For the first phase of peace projects, various NGOs such as PTN, Friends Church Peace Team (FCPT), and Turning The Tide (TTT) operating in the region conducted trainings on human rights and advocacy for peace in four divisions of the region, namely Kaptama, Kapsokwony, Kopsiro and Cheptais sub counties attended by selected youth, as one of the means of building the capacity of the youth to engage with 
their leaders and advocate for issues that create peace and development in their communities.

This was meant to ensure effective implementation of the skills acquired, and together with the youth in Mt. Elgon develop a strategic plan with the priority concern on civic education with actions and activities to be implemented as a way forward to achieve peace in the region. Civic education in the area was further meant to ensure that the youth were peacefully united and also to give them the ability to participate non violence in the land issues. One such initiative was carried out by the Friends Church of Kenya.

\section{Quaker Peace Building Programs}

In the middle of the violent chaos, the Friends Church Peace Teams (FCPT) which had been formed by Kenyan Quakers began immediate visits to IDP camps and distributed relief items. The FCPT, in partnership with the African Great Lakes Initiative (AGILI) of Friends Church Peace Teams, visited the camps in Chwele which boosted many Mt. Elgon victims.

The programs that AGILI/FCPT conducted since the outbreak of violence in the Mt. Elgon area were intended to help people recover atrocities and to prevent the reemergence of violence. The Quaker programme adapted to the immediate needs of Mt. Elgon residents. It adapted the approach of alternative to violence approach. This was done through workshops conducted by AGILI/FCPT that taught participants non violent means of resolving conflicts. It involved three levels basic, advanced, and training for facilitators. The Alternative to Violence Programme (AVP) workshops used the shared experience of participants, interactive exercises, games and role plays to examine the ways in which people respond to situations where injustice, prejudice, frustration and anger can lead to aggressive behavior and violence.

The respondents said they had no difficulties in getting jobs to earn a living. The jobs they easily got were the manual jobs that did not require much skill. This is in line with what Larsen (2013) said that those hiring people should not reject the demobilized person because they are demobilized. When they are looking for work, many men and women seek out informal employment where they don't need much training or literacy skills and also where they don't have to detail out any work past experience such as jobs in agriculture or construction.
On rehabilitation they said that there were three categories of people depending on their level of rehabilitation. The first one is for those who had been rehabilitated fully. These ones are successful for example the school going age went back to school to complete their studies. Three of those who went back to school managed to go to the university while a few others were trained at lower levels. The second category is for those who didn't see the value of rehabilitation. They felt that the time spent in the reintegration programs was a waste and that there were no financial gains and as a result they reverted back. The third category was that one of those who were not rehabilitated. These ones were not easily found and so they could not attend the programmes.

The objective examined the contribution of the reintegration of former combatants on inclusion and equity in Mount Elgon

The Peace Tree Network organizers tried to enhance capacities and inclusion of the Mount Elgon youth in the National Reform Processes so as to solve the long standing land issue and improve their livelihood but all the efforts seemed to fail as the violence escalated.

To reduce their capacity for destabilization, former combatants will usually need specifically designed, sustainable support to help them with their transition from military to civilian life. The reintegration and reconciliation of former combatants must therefore be part of the recovery strategies for all war affected populations. Reintegration programmes should also aim to build local and national capacities to manage the process in the long term, as reintegration increasingly turns into reconstruction and development.

\section{References}

[1] Africa Renewal (2007). Improving the Reintegration of Former Combatants. United Nations. New York, NY 10017 USA

[2] Avramov, D. (2002). People, demography, and social exclusion. Number 37 in Population Studies Series, Strasbourg, Belgium: Council of European Publishing.

[3] Berdal, M.\& Ucko, D.H. (eds), Reintegrating Armed Groups after Conflict, Politics, Violence and Transitions, London: Routledge, 2009,p2

[4] Best, J. \& Kahn, J. (2004). Research in Education ( $7^{\text {th }}$ Edition); New Delhi: Prentice Hall of India Private Limited

[5] Buxton, J. (2008). Reintegration and Long Term Development: Linkages and challenges. 
Thematic Working Paper 5. Bradford Centre for International Cooperation and Secuirity. University of Bradford

[6] Dane, F. C., (1990). Research Methods; Brookole: Pacific Groove

[7] Denov, M. (2010). Coping with the Trauma of War: Former Child Soldiers on Post Conflict Sierra Leone. International Social Work, 53(6)

[8] Fusato, M. (2003). Moving Beyond Intractability. Disarmament, Demobilization, and Reintegration of Ex-combatants. Beyond Intractability, Eds. Guy Burges and Heidi Burges. Conflict Information Consortium, University of Colorado, Boulder.

[9] Lombe, M. (2007). Presentation Given at an Expert Group Meeting on Creating an Inclusive Society: Practical Strategies to Promote Social Integration, Paris, France, 10-13 September 2007

[10] Larsen, C. A. (2013). The Rise and Fall of Social Cohesion. The Construction and Reconstruction of Social Trust in the USA, UK, Sweden and Norway. Oxford University Press.

[11] Lotscher, W. (2016). Reintegration of ExCombatants and Reconciliation in Rwanda: A Case Study. NADEL MAS- Cycle 2014-2016

[12] Mugenda, M. O. \& Mugenda, G. A. (2003). Research Methods: Quantitative and Qualitative Approaches, Nairobi. Acts Press.

[13] Munive, J. \& Stepputat, F.(2015). Rethinking Disarmament, Demobilization and Reintegration Programmes. Stability, International Journal of Security \& Development, 4 (1), 1-13

[14] Ozerdem, A. \& Podder, S. (2011). "Disarming Youth Combatants: Mitigating Youth Radicalization and Violent Extremism" in Journal of Strategic Security (JSS) Volume 4 Number 4,

[15] Therborn, G. (2007). Presentation. Expert Group Meeting on Creating an Inclusive Society an Inclusive Society: Practical Strategies to Promote Social Integration, Paris, France, 10-13 September 2007

[16] Torjesen, S., (2013). Towards a theory of ex-combatant reintegration. Stability: International Journal of Security and Development. 2(3), p. Art. 63. DOI: http://doi.org/10.5334/sta.cx

[17] United Nations. (2006). Operational Guide to the Integral Disarmament, Demobilization and Reintegration Standards. New York. United Nations. http://www.unddr.org
[18] Vindevoge, S., Coppers, K., Derluyn, I., De Schryver, M., Loots, G., \& Broekaert, E., (2011). Forced Conscription of Children during Armed conflict: Experiences of Former Child Soldiers in Northern Uganda. Child abuse and Neglect,35(7) 